\title{
メーソンリーユニットの力学的試験方法の改善 および圧縮性状に関する実験的研究 \\ AN EXPERIMENTAL STUDY ON METHODS FOR CLARIFYING MECHANICAL BEHAVIORS OF MASONRY UNITS UNDER UNIAXIAL LOADINGS
}

\author{
馬場 明生*, 千歩 修**, 河原利 江***, 守 明子****, 高橋和雄***** \\ Akio BABA, Osamu SENBU, Rie KAWAHARA, \\ Akiko MORI and Kazuo TAKAHASHI
}

\begin{abstract}
This paper deals with a proposal on a standard experimental test method for clarifying compressive strength and deformation characteristics of masonry units mainly focused on quality control. As a result, small prism specimens with height to width ratio of 2.00 are proposed for performing the exact measurements of their elastic modulus. Furthermore, the following technical items are clarified;

1) The relationships between compressive strength and Young's modulus in the cases of burnt clay and concrete units.

2) Critical and initiation stress value under compressive loadings on the basis of volumetric strain features

3) Predictive methods of three dimensional strains on the basis of Young's modulus and Poison's ratio changes under the process of uniaxial loadings
\end{abstract}

Keywords: masonry units, mechanical charact eristics, standard method メーソンリーユニット, 物理的特徵, 標準試験方法

1.はじめに

メーソンリー構造（組積造）“は、世界中で最も多くの人々が居 住する建築構造であるにも関わらず、地震被害において多くの人々 の命が失われてきている。しかし、この伝統的な建築構造に関して は、耐震性能が明確でないだけでなく、その性能を確保するために、 最も基本的な建築材料であるメーソンリーユニット（組積単体とも 呼称するか、ここでは以後ユニットと呼称する。）に求められる性質、 すなわち構造設計における材料強度の試験方法についてすら明確で ないのが現状である。一方、諸外国における品質規格の不統一およ び矛盾を放置した状態としているだけでなく、その結果、同種構造 の構造性能の向上を遅らせる結果とすらなっている。我が国におい ても、メーソンリー構造のユニットの JIS 規格”2における試験方法 は統一されておらず、同構造を安定して生産する支障となっている。 また、メーソンリー構造の耐久性における利点を注目して耐震性・ 耐久性に優れた耐火造である鉄筋コンクリート組積造の普及が行わ れているか、そのための型枠状ユニットの試験方法についても統一 されておらず、各種材質のユニットに関する共通な情報の普及が妨 げられている。さらに、最近重要となりつつあるコンヴァージョン 的な改修の代表としての明治・大正期の焼成粘土煉瓦 ${ }^{* 3}$ を用いた文 化財建造物として無筋メーソンリー構造の耐震性評価方法の確立が
求められており、この場合においても不正確な材料強度評価が実施 されていることが多く、評価方法の定式化が強く望まれている。

したがって、ここでは標準的な試験方法について提案し、その結 果として得られた圧縮強度・ヤング係数・ポアソン比およびそれら における関連性などについて明確とすることを目的としている。そ の結果、より性能の安定したメーソンリー構造を普及することに貢 献できると考える。

\section{2. 既往の研究}

ユニットは適用する建築構工法によって中実・穴あき・空洞およ び型枠状と各種の形状に分けられるだけでなく、粘土焼成（セラミ ックス質と呼称する。)・コンクリート・珪酸カルシウムなど各種の 材質にも分類されており、このような現状が圧縮強度などの力学試 験を混沌とした状態としている。すなわち、既往のユニットの圧縮 強度試験方法について調查すると、ユニットの圧縮試験法はメーソ ンリー構造における最も重要な構造材料に関する試験法であるにも かかわらず、旧 JIS 規格および各国規格においては空洞部を含めた ユニットの全形または半裁を圧縮する形態の試験方法が基本的に採 用されてきた。この試験方法は構造耐力上有効ではない空洞や細孔 を包含してユニットの全断面の強度（全断面強度と呼称する。）を評

\footnotetext{
本研究は、これまで BRI Research Paper1および日本建築学会大会学術講演梗概集吼に発表したものを編集して取りまとめたものである。

*山口大学工学部感性デザイン工学科 教授・工博 — Prof., Dept. of Perceptual Design and Engineering, Faculty of Eng., Yamaguchi

**北海道大学大学院工学研究科建築材料研究室 教授・ 工博

*** 山口大学工学部感性デザイン工学科 助手・修士(工学)

**** 名古屋工業大学大学院つくり領域 教授・博士 (工学)

***** 太陽セメント工業(称)
} 
価するのには一定の意味は有しているが、ユニットの実質部を構成 している材料そのものの力学的な性質などの構造設計上の必要な物 理的諸性質を解明する観点からは不十分であり、特に形状とは一様 独立した強度・ヤング係数・ポアソン比などの構造設計にとって不 可欠な力学的性質を求めることができないだけでなく、扁平なユニ ットを活用する試験法では圧縮強度すら求めることができないのが 現状である。

Table1に現行の代表的なユニットの圧縮強度試験法の概要を示す •4。同表においては主として以下の点で異なっている。
1) 全形および切り出しの差異
2 ）試験体の形状
3 ) キャッピングの方法
4 ）異方性と使用方法との関連
5 ) 試験に必要なその他の資材の影響

\section{3. 研究方法}

\section{1 圧縮試験方法の比較検討}

既往のユニットの圧縮強度試験方法について調查の結果、ユニ ットの材質を同定するための以下に示すような標準的な試験体を 用いる方法としては、以下の要素を含むようにした。

1) 試験体は高さと底辺の長さとの比は, 中心部の破壊に端部拘 束の影響が小さいように $2: 1$ とする。

2 ) 試験体の底辺長さは、実際のユニットから採取可能な限りに おいて大きくする。

3 ）キャッピング材は、試験体の強度より大きい材料を選択して 可能な限り薄く用いる。

4 ）試験体は、現実の使用状態における鉛直方向を加力方向とす る。

5 ) 試験体は、軸方向ひずみのみでなく横方向ひずみを測定でき るような寸法および表面形状とする。

結果としてユニットの圧縮試験体は、Figure1 のように高さの小さ い煉瓦では試験体の高さをユニットの高さとするように、また空洞
および型枠状ユニットの場合はフェイスシェル厚さを試験体の底辺 の長さとするように採取することとなる。ここで試験体が小さい場 合には強度值の変動を考虑して適宜試験体の本数を増大することと なる。ここでは、シリーズ 1 で 5 本、その他では基本的に 3 本の平 均を採ることとした。荷重速度は圧縮応力度か $0.1 \mathrm{MPa} / \mathrm{s}$ となるよう にした。

実験は、底辺の長さを $3 \mathrm{~cm}$ で高さを $6 \mathrm{~cm}$ とする標準試験体を基準 として、Table1 に示す種類の試験方法に多いユニットの半裁をキャ ピングしたものと比較した。そのとき各部のひずみの分布に変化を 観察した。標準的な試験体の圧縮状態を Photograph1に示す。その 他、実験は Table2 に示すように加圧盤の厚さ・異方性・含水状態な どの影響を解明できるように、シリーズ 1 および 2 とした。

\section{2 変形性状の測定}

構造設計に必要な各種弾性係数を求めるために、我国の代表的な 市販のセラミックス質 14 種、コンクリート質 27 種のユニットにつ いてのシリーズ 3 の実験を実施した。ここでは Figure2 に示すよう にワイヤーストレインゲージを貼付した。軸方向ひずみは相対する 2 面の值の平均、横方向ひずみも相対する値の平均とした。ここで、 文化財建造物に多い小口面をダイ開口とする押出成形粘土焼成棟瓦 のような異方性のある場合には、横方向ひずみの測定は 2 対の相対 する面に対しても測定する必要がある。

これらの測定の結果、ヤング係数およびポアソン比を求めること ができるだけでなく、それらの軸方向ひずみに対する体積ひずみな

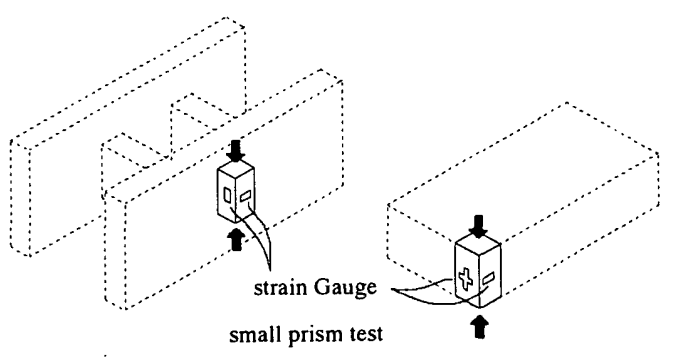

Figure 1 Method for making specimens from actual units

Table1 Past methods for determining the compressive strength of masonry units ${ }^{*}$

\begin{tabular}{|c|c|c|c|c|c|c|}
\hline Code & $\begin{array}{l}\text { JIS R 1250-1981 } \\
\text { Common Clay } \\
\text { Bricks }^{2)}\end{array}$ & $\begin{array}{l}\text { JIS R 2206-1977 } \\
\text { Fireproof Clay } \\
\text { Bricks }\end{array}$ & $\begin{array}{l}\text { JIS A 5406-1979 } \\
\text { Hollow Concrete } \\
\text { Blocks }{ }^{3} \\
\text { JIS A 5210-1975 } \\
\text { Ceramics Blocks }{ }^{4}\end{array}$ & $\begin{array}{l}\text { ASTM C 67-81 } \\
\text { Sampling and } \\
\text { Testing Clay } \\
\text { Masonry Units }\end{array}$ & $\begin{array}{l}\text { ASTM C } 140-75 \\
\text { Sampling and } \\
\text { Testing Concrete } \\
\text { Masonry Units }\end{array}$ & $\begin{array}{l}\text { BS } 392174 \\
\text { Clay Bricks } \\
\text { and Blocks }\end{array}$ \\
\hline $\begin{array}{l}\text { Shape of } \\
\text { direction } \\
\text { of } \\
\text { Loading }\end{array}$ & half size & $\begin{array}{l}\text { cubic } \\
(60 \times 60 \times \\
60 \mathrm{~mm})\end{array}$ & full size & $\begin{array}{l}\text { half size } \\
\text { (quarter) }\end{array}$ & full size & full size \\
\hline $\begin{array}{l}\text { Condition } \\
\text { of } \\
\text { Specimen }\end{array}$ & - & $\begin{array}{l}\text { absolute dry } \\
\left(105^{\circ} \mathrm{C}-120^{\circ} \mathrm{C}\right)\end{array}$ & $\begin{array}{l}\text { wet } \\
\text { (more than 2h) }\end{array}$ & $\begin{array}{l}\text { absolute dry } \\
\left(105^{\circ} \mathrm{C}-115^{\circ} \mathrm{C}\right) \\
\text { and cool } \\
24 \pm 8^{\circ} \mathrm{C} \\
(30-70 \% \mathrm{RH})\end{array}$ & air dry & $\begin{array}{l}\text { - wet(more than } \\
24 \mathrm{~h}) \\
\text { - saturated } \\
\text { under vacuum } \\
\text { - saturated by } \\
\text { boiling }\end{array}$ \\
\hline Capping & $\begin{array}{l}\text { - no-capping } \\
\text { - paper } \\
\text { - rubber }\end{array}$ & $\begin{array}{l}\text { - no-capping } \\
\text { - paper }\end{array}$ & $\begin{array}{l}\text { mortar } \\
\text { gypsum } \\
\quad+\text { cement } \\
\text { gypsum } \\
\text { (no-capping) }\end{array}$ & $\begin{array}{l}\text { - gypsum } \\
\text { - } \text { sulfur-filler } \\
\text { - mortar }\end{array}$ & $\begin{array}{l}\text { - sulfur } \\
\cdot \text { gypsum }\end{array}$ & $\begin{array}{l}\text { - mortar } \\
\text { - plywood sheet }\end{array}$ \\
\hline
\end{tabular}




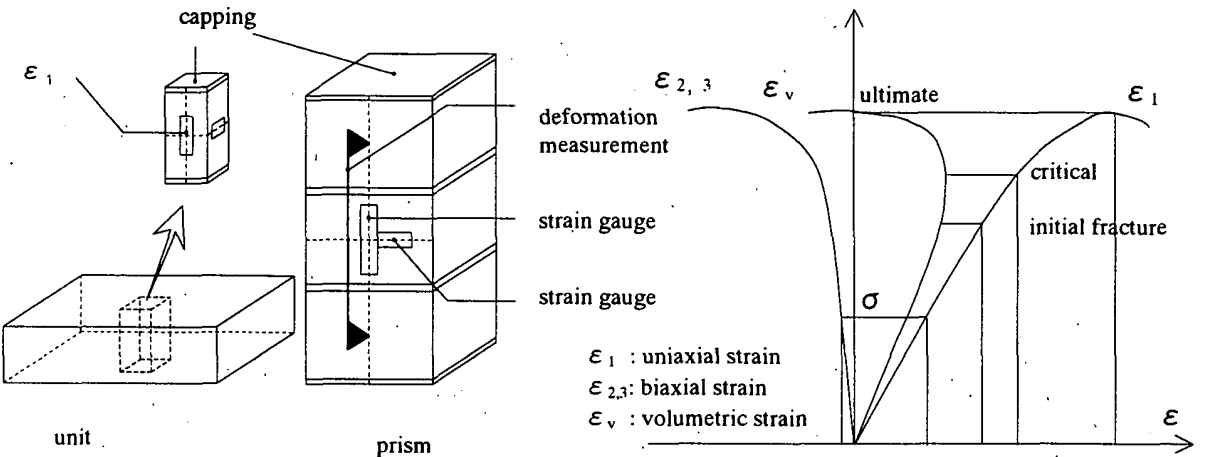

Figure2 Method for measuring uniaxial and biaxial strain of units under axial loading and for identifying initiation and critical point of fractures

どの変化を観察することによって、ユニットの内部破壊 点や破壊臨界点の指標を得ることができる。さらに、メ ーソンリー構造を構成する基本的な複合材料であるユニ ットを目地モルタルで組積した組積体（組積プリズムと 呼称する。)についても同様に変形性状を測定することに よって、組積プリズムの庄縮強度だけでなく、ヤング係 数およびポアソン比などを求めることができる。

\section{3 ユニットの破壞プロセスの同定手法}

\section{シリーズ 3 におけるユニット圧縮試験における各種ひ}

ずみの測定から体積ひずみを測定することによってユニットの破壊 開始応力度および破壊臨界応力度を求めることができる゙5。こで は、Figure2 に示すように体積ひずみと縦応力度との関係が比例関係 から脰張側に移行し始めるときを破壊開始応力度、体積ひずみの極、 值を破壊臨界応力度と定義する。また、これらの応力度における縦 ひずみを破壊開始ひずみおよび破壊臨界ひずみと呼称することどし た。

\section{4 実験に用いたユニット}

実験に用いたユニットは、Table2 に示すように各種の断面形状お よび材質を尽くすことができるようにするとともに、研究の目的か ら以下の $3 つ の$ 実験シリーズに位置つけた。

シリース $1:$ 強度範囲の広いセラミックス質のユニットを用いて、 圧縮強度試験にとって前提的な条件であるキャッピン グおよび乾湿状態について検討

シリース $2:$ 試験体の形状および加圧盤の条件の影響

シリーズ 3 : 圧縮強度のみならずヤング係数・ポアソン比、破壊プ ロセスの同定、ならびに圧縮系複合応力状態の構成方 程式の確立

\section{4. 実験結果}

\section{1 圧縮強度に対する試験方法の影響}

シリース 1 の 5 種類の粘土から製造された標準形中実断面形状の ユニットの圧縮強度に関してキャッピングの有無・試験時の水分状 態および押出成形の方向という 3 つの影響の組合せで 5 体の平均值 で評価した結果を、それそれ Figure3・4および 5 に示す。

Figure3 に示すようにキャッピングしないで研磨したユニットの 圧縮強度は吸水率が小さくなると大きくなるが、イオウキャッピン グしたユニットは高強度ユニットではキャッピングなしより強度が
Table2 Brief expression of experimental procedures in the study

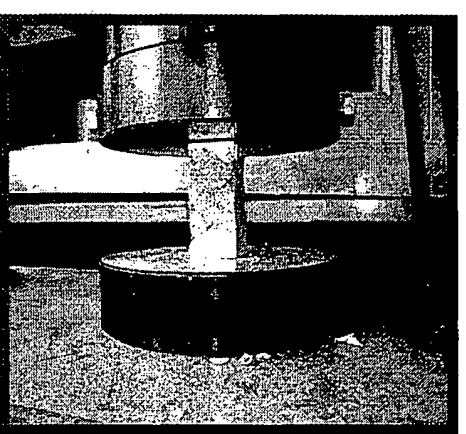

Photograph 1 Actual feature of test methods

\begin{tabular}{l|l|l|l|l}
$\begin{array}{l}\text { No.of } \\
\text { Series }\end{array}$ & $\begin{array}{l}\text { Kind of } \\
\text { materials }\end{array}$ & $\begin{array}{l}\text { Number of } \\
\text { unit kinds }\end{array}$ & $\begin{array}{l}\text { Nominal size of } \\
\text { specimens }(\mathrm{mm})\end{array}$ & $\begin{array}{l}\text { Main parameter of } \\
\text { experiments }\end{array}$ \\
\hline Series 1 & clay & five & $30 \times 30 \times 60$ & $\begin{array}{l}\text { capping, isotropic and } \\
\text { moisture conditions }\end{array}$ \\
\hline Series 2 & clay & three & $\begin{array}{l}30 \times 30 \times 60, \\
\text { full size }\end{array}$ & shapes of specimens \\
\cline { 2 - 5 } & concrete & ten & $\begin{array}{l}30 \times 30 \times 60, \\
\text { full size }\end{array}$ & shapes of specimens \\
\hline Series 3 & clay & fourteen & $30 \times 30 \times 60$ & $\begin{array}{l}\text { strength level of } \\
\text { materials }\end{array}$ \\
\cline { 2 - 5 } & concrete & twenty seven & $30 \times 30 \times 60$ & $\begin{array}{l}\text { strength level } \\
\text { of materials }\end{array}$ \\
\hline
\end{tabular}

小さかった。また、50MPa 以下ではキャッピングの効果があり、前 者の変動係数か $11.83 \%$ に対して後者は $18.80 \%$ と概方変動の少ない 結果が得られた。したがって、高強度のものを除けば、キャッピン グによって正しい強度が求められるが、概ね 50MPa より大きいとき はキャッピング材料よりユニット強度が大きくなり、精密な結果が 得られない。また、試験時の水分状態の影響に関して Figure4 に示 すように一部の低強度のものを除いてほぼ同一となった。さらに、 押出成形方向との関連では、一部押出成形方向の圧縮強度が幾分大 きくなる結果となった。

\section{2 全形圧縮試験と比較}

シリーズ 2 の全形試験結果とここで提案している試験方法、すな わち小型プリズム試験体との比較を Figure6 に示す。ここで、キャ ッピングありの場合は、操作性より高強度の $\alpha$ 石膏を用いた。また、 ここでは加圧盤の厚さの影響”6についても比較している。同様の試 験を研究対象ユニットの製造会社で実施した結果も示している。こ こで、この試験体も含めて $\alpha$ 石膏キャッピングに厚めの加圧盤を用 いた。同図に示すように本提案の標準試験法で得られる圧縮強度に 対して、他の方法では強度が大きくなるにつれて小さめの圧縮強度 となっている。その傾向は、標準試験体による圧縮強度が概ね $40 \mathrm{MPa}$ より大きくなると著しく全形試験高品質ユニットの圧縮強 度には不適切であることが示されている。

一方、同シリーズの全形試験におけるひずみ並びにフェイスシェ ル表(a)裏(b)およびウェブにおける破壊発生の例をそれぞれ Figure7 および 8 に示す。全形試験は、前図に示すように粘土焼成ユニット の全形試験ではキャッピングおよび加圧盤をエ夫してもひずみは正 確に測定できなかった。また後図に示すようにユニットの形状によ る固有の局部的な破壊が進行することから材質試験としてては不適切 である。 

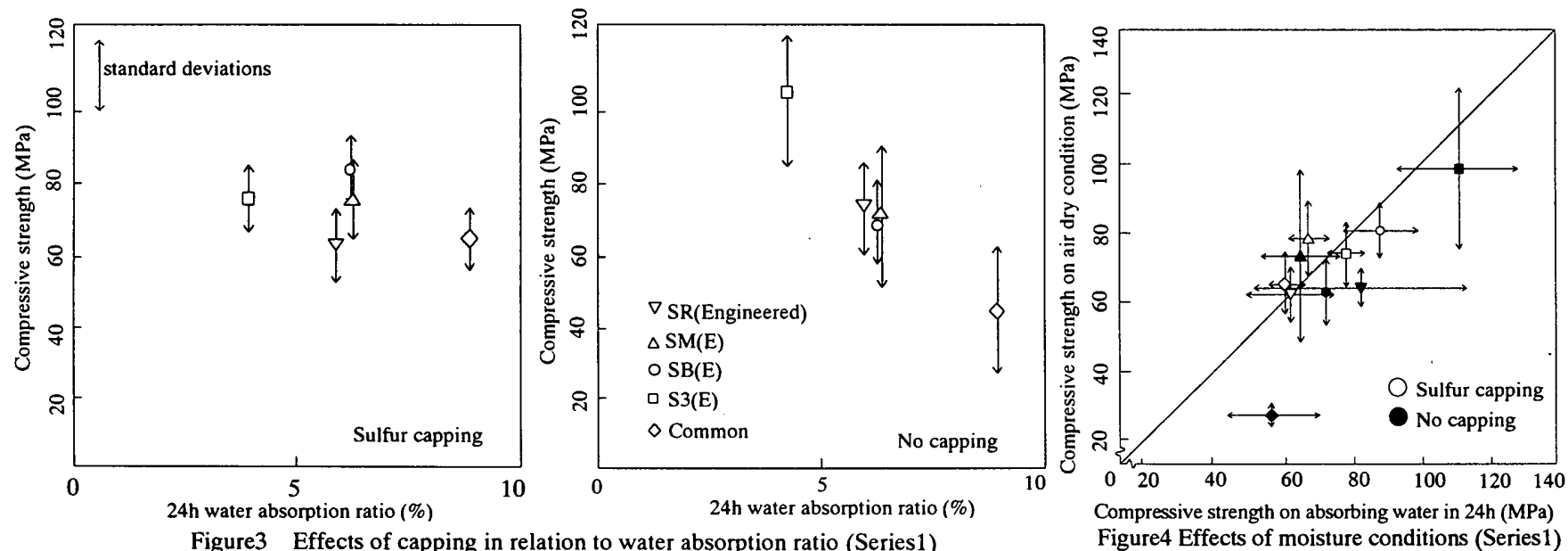

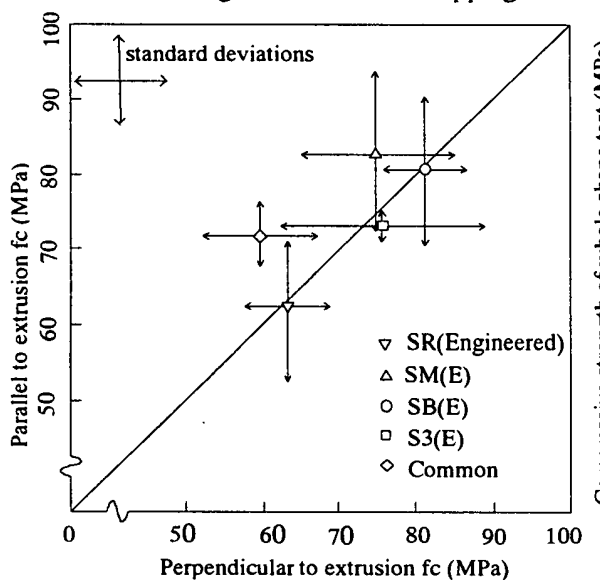

Figure 5 Effects of directions of extrusion moulding (Series1)
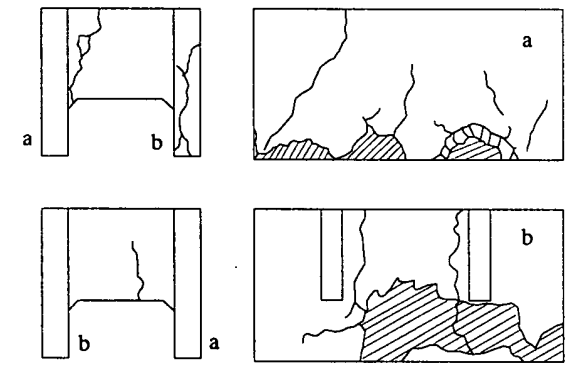

OFBS30 No capping

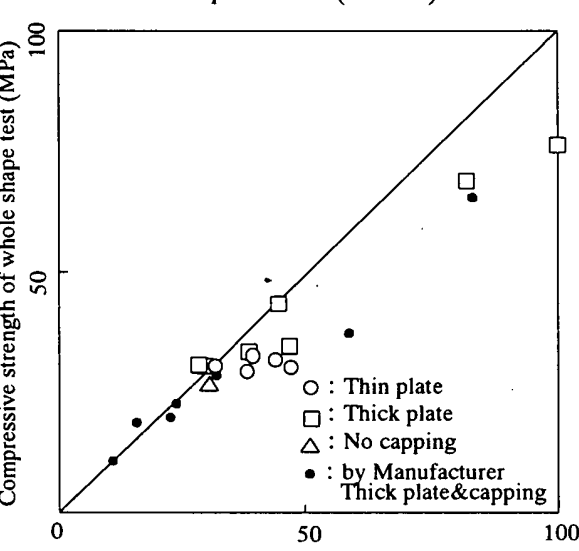

Compressive strength of coupon shape test (MPa) Figure6 Comparison between small prism and whole shape tests (Series2)
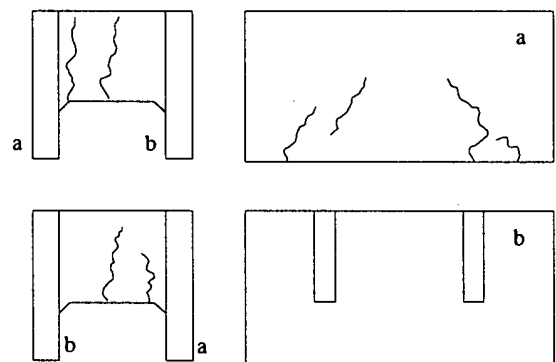

OFBS30(1)

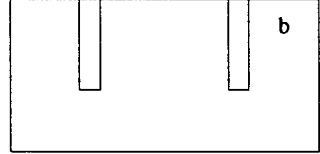
Gypsum capping
Thin plate

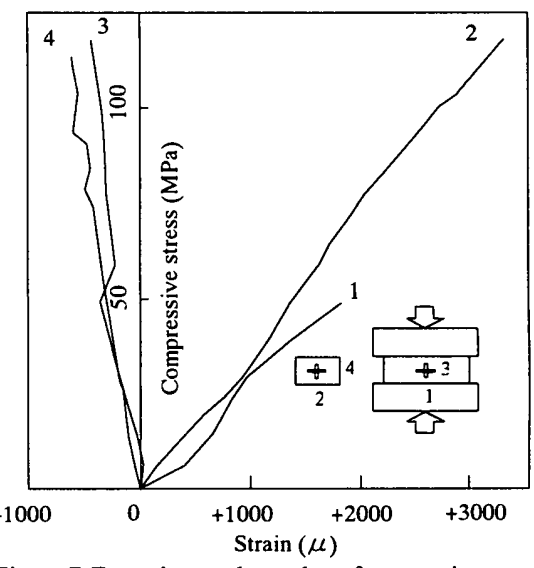

Figure7 Experimental results of measuring strain of whole shape specimens (Series2)
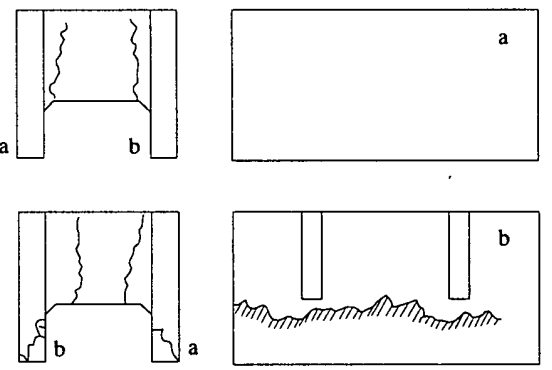

OFBS30(2) Gypsum capping Thick plate

Figure8 Experimental results on fracture features in whole shape specimens (Series2)

\section{3 圧縮変形性状およひ弾性係数}

シリース 3 の標準試験によって得られた応力ひずみ関係の実験結

果の例を Figure9 に示す。Figure9 に示すように、コンクリート系ユ ニットは、一般的な現場打設のコンクリートと同様に初期において は弾性的な挙動を示すが、より高応カレベルにおいてはより大きな ひずみとなった。一方、セラミックスユニットではほぼ終局強度ま で概ね弾性的な挙動を示した。また、同シリーズにおける圧縮強度 とヤング係数との関係および圧縮強度とポアソン比との関係をそれ それ Figure10 および 11 に示す。詳細に観ると前者は比較的強度が 小さい範囲 (約 $50 \mathrm{MPa}$ 以下) ではヤング係数は強度とともに急激に 增大し、高強度の範囲では強度とともに緩慢にしか增大しないとい ういわゆる現場打設コンクリートにおける同関係と同様の傾向とな るか、後者におけるヤング係数は圧縮強度とともにほぼ直線的に增
大する傾向となり、結果として最も構造体として用いられている $50 \mathrm{MPa}$ 以下の低強度では同一強度のときのヤング係数はセラミッ クスユニットがコンクリートユニットと比較してより小さいことが 明確となった。すなわち、コンクリートユニットの場合には、グラ ウトメーソンリーとして使用するときにユニットとグラウトとが同 一ひずみとなると仮定すると、内部のコンクリートなどのグラウト に強度比以上に応力を生じユニット破壊することになると考えられ る。さらに、高強度のセラミックスユニットの場合はヤング係数が 大きくなり、それに適合する目地材料が得られ難いために組積状態 における強度が得られにくい結果となると考えられる。

次に圧縮強度とポアソン比との関係を Figure11 に示す。同図に示 すように、圧縮強度が大きくなるにつれて概ね 0.20 程度の安定した 值となるが、20MPa の以下の低強度では極端に大きなポアソン比ゃ 

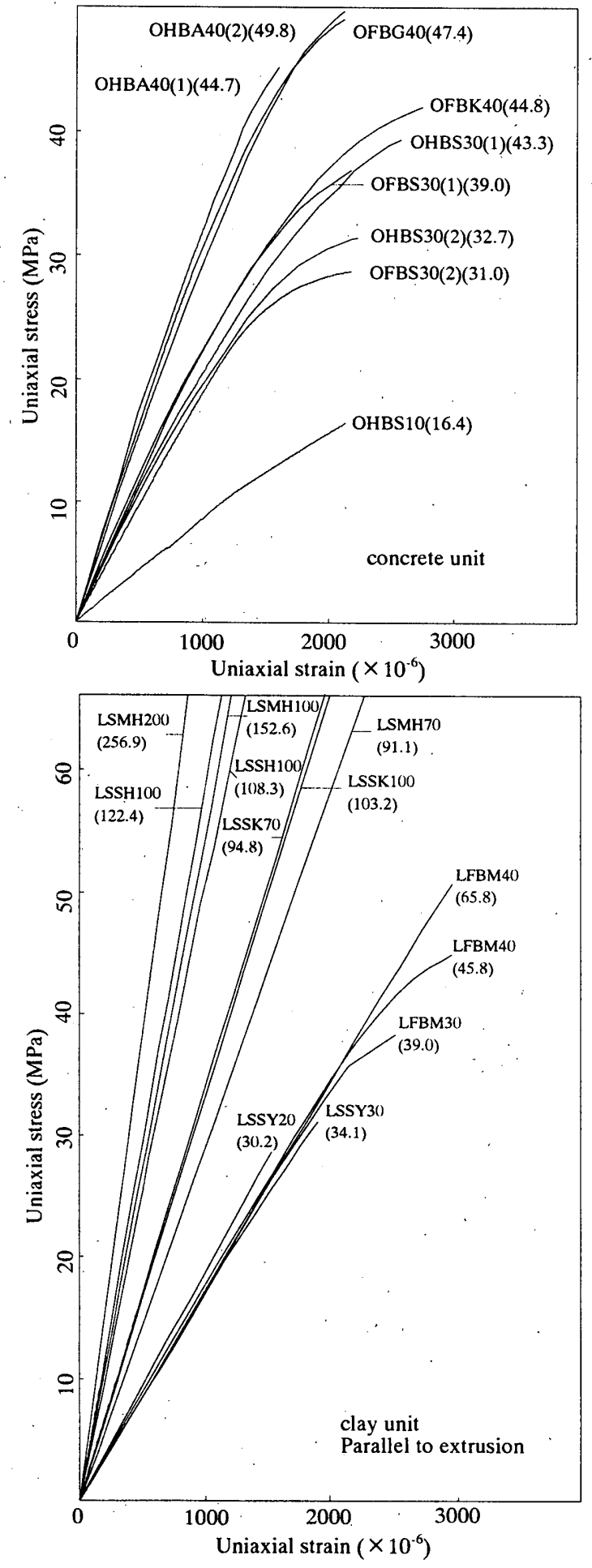

Figure9 Stress and strain relationship of concrete and clay units under uniaxial compressive load

小さなポアソン比となる傾向となった。特にその傾向はセラミック スユニットにおいて著しく、低強度の同材質においては混練・焼成 などの製造プロセスにおける押出成形による異方性が大きく現れる など材質の不均質さによるものと考えられる。

\section{5. 考察}

5. 1 圧縮応力下における破壊プロセス

圧縮強度は他強度と比較して試験し易く、構造設計の場合には脆

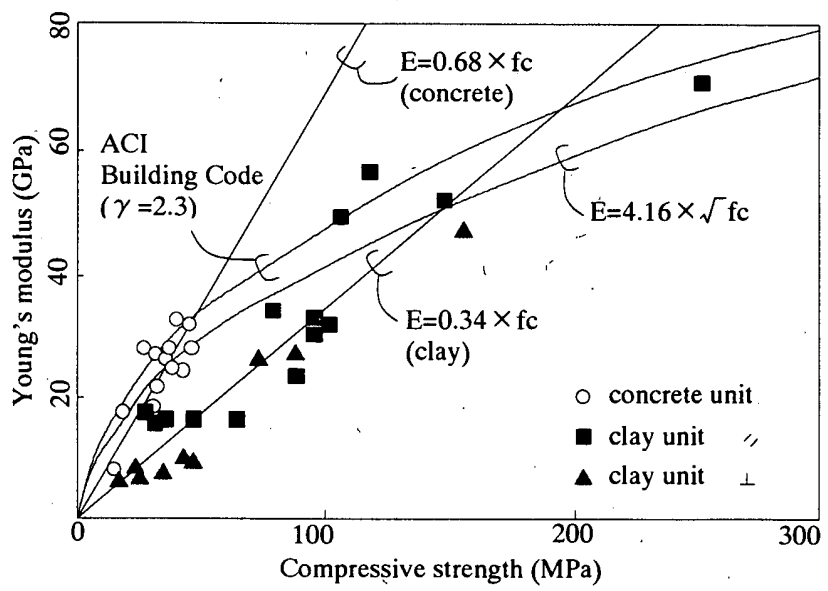

Figure10 Relationships between young's modulus and compressive strength of masonry units

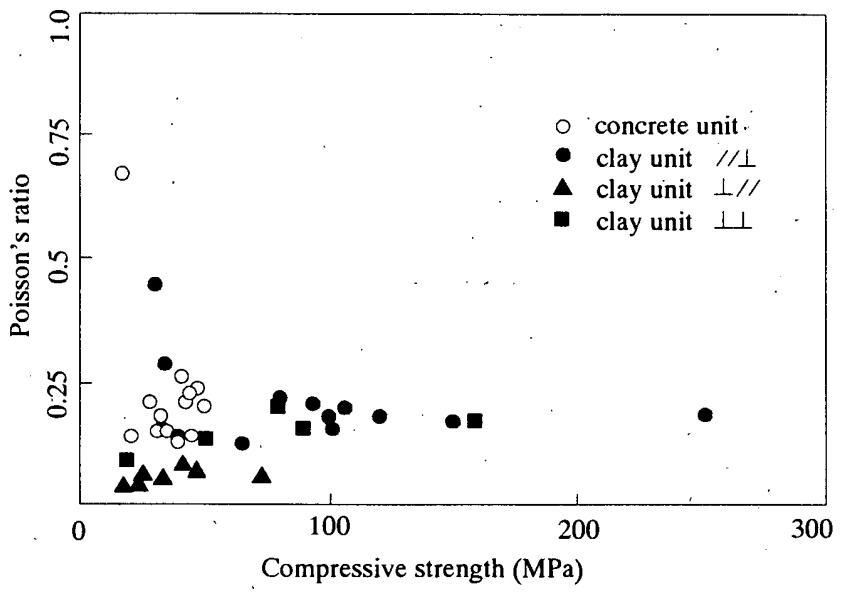

Figure11 Relationships between poisson's ratio and compressive strength of masonry units

性構造材料を用いた建築構造の基本的な材料強度として活用されて いる。ユニットを圧縮するときの破壊は圧縮強度時に突然生じる訳 ではなく、圧縮応力がより小さいレベルから微細ひび割れ等の破壊 が発生することが一般的には考えられる ${ }^{9}$ 。すなわち、同一の圧縮 強度であっても破壊が早期に発生しているものとそうでないものと があるということとなり、各種外力作用に対する許容応力度を確定 するためには、このような破壊プロセスについて把握しておくこと が求められる。ここでは、圧縮加力時の縦ひずみ・横びずみおよび それらから計算される体積ひずみと縦ひずみとの実験結果から 3.3 で述べた破壊プロセスの同定方法による破壊臨界応力度を求めた。 この破壊臨界応力度と終局圧縮強度との比（破壊臨界応力度比と呼 称する。）を縦軸とし、終局圧縮強度を横軸とした関係を Figure12 に示す。同図に示すようにコンクリートユニットでは破壊臨界応力 度比すべての実験結果が 0.8 以上となっているのに対して、セラミ ックス系ユニットでは 0.27 から 0.96 と広範囲となっており、この ことは構造設計における許容応力の設定において考虑するべきであ る。同図に参考のための一般的な強度のコンクリートと目地モル夕 ルおよびグラウトモルタルとして最も一般的な強度の材料”7につい て比較している。グラウトコンクリートでは 0.72、グラウトモルタ ルでは 0.84、さらに目地モルタルでは 0.95 となった。それに比較し てコンクリートユニットでは 0.82 から 0.96 と大きな值となったの は、振動加圧成形によるコンクリートの最大寸法が $10 \mathrm{~mm}$ 程度と比 


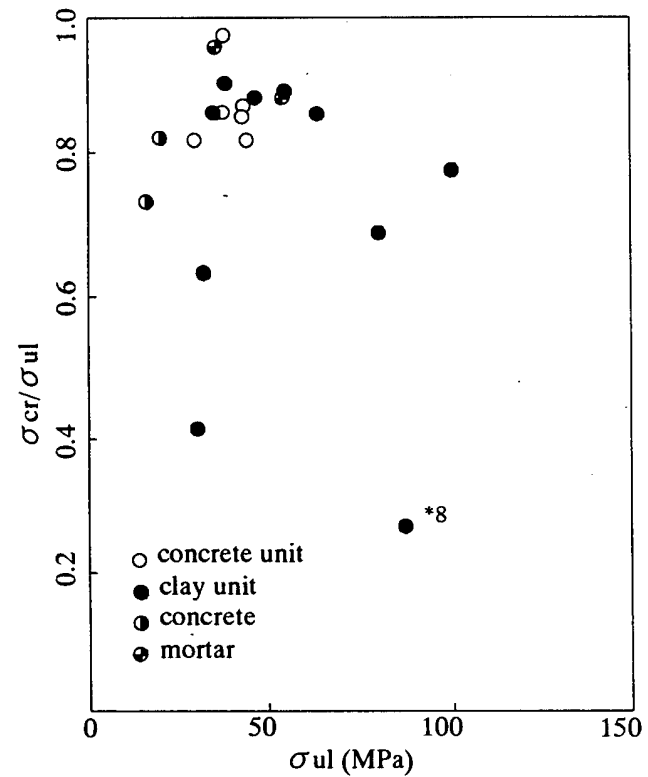

Figure 12 Experimental relationships between critical stress ratio and ultimate strength of masonry units (Note; Ordinary concrete and mortar are plotted in the this diagram in comparison with masonry units.)

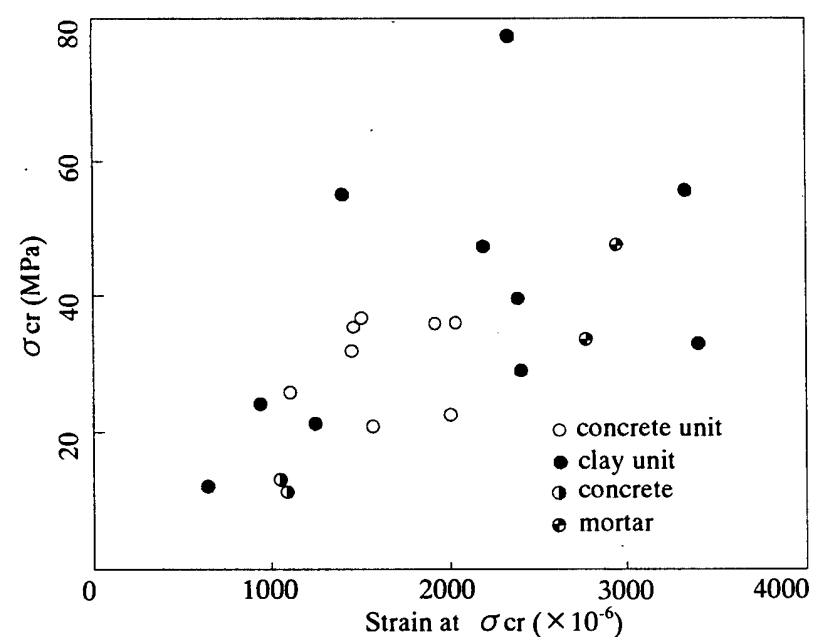

Figure 13 Experimental relationships between critical stress and critical strain of masonry units

(Note; Ordinary concrete and mortar are plotted in the this diagram in comparison with masonry units.)

較的小さくモルタルに近いコンクリートであるため、上述のモル夕 ルとコンクリートの間となったと考えられる。

さらに、破壊臨界応力度とそのときの縦ひずみ、破壊臨界ひずみ との関係を Figure13 に示す。同図に示すように一般的なコンクリー

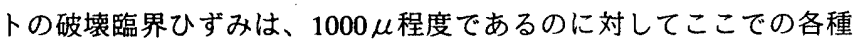
モルタルでは $3000 \mu$ 程度となり、コンクリートユニットはその間の 值となっている。それに対してセラミックスユニットは $600 \mu$ から $3300 \mu$ までと広範囲となっており、構造材料として用いる場合、臨 界状態の応力とひずみとを把握することが望まれる。これらの関係 は概ね臨界ひずみ度が增大するにしたがって臨界応力度が大きくな る傾向はあるが、その下限域に位置する材料から上限域に位置する 材料までと幅があり、それは畑の底土すなわち雑粘土を原料とする ものと精製粘土を原料とするものの差であると考えられる。コンク リートに関しては上述の関係の中程度以下から下限の間に位置して いる。
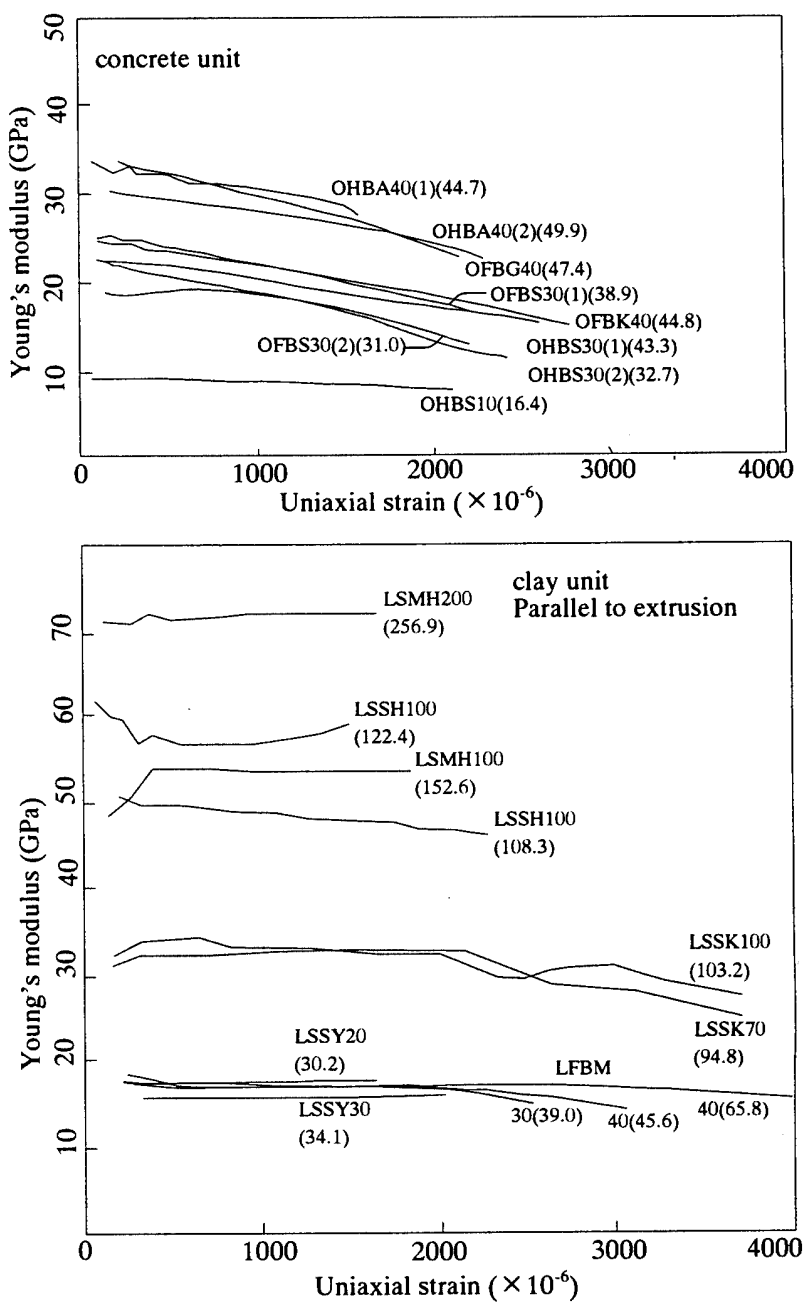

Figure14 Relationships between young's modulus and uniaxial strain of concrete units and clay units under uniaxial compressive load
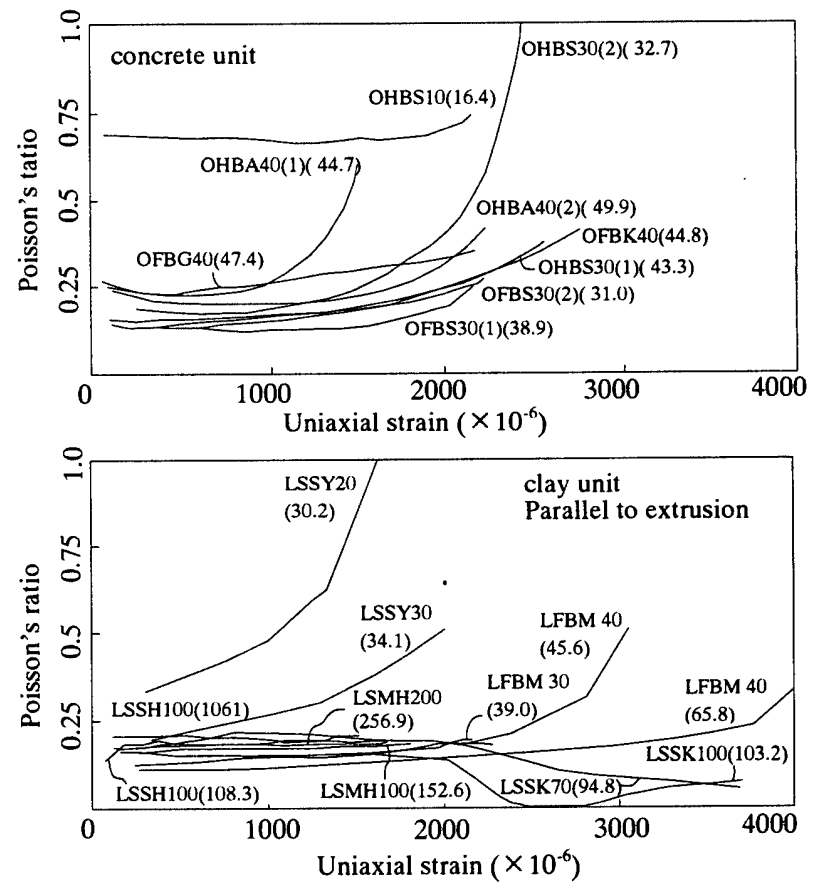

Figure15 Relationships between poisson's ratio and uniaxial strain of concrete units and clay units under uniaxial compressive load 
5.2 ヤング係数およびポアソン比の変化の定量評価

シリース 3 の実験結果よりヤング係数と縦ひずみとの関係を Figure14に、ポアソン比と縦ひずみとの関係を Figure15に示す。同 図に示すようにコンクリートユニットのヤング係数は縦ひずみとと もに徐々に低下する傾向となるが，セラミックスユニットではほぼ 一定となる。また，ポアソン比は両材質とも初期においては一定で あるものの縦ひずみの増大とともに増大する傾向となる。以上をま とめると下式で表現できる。

$\mathrm{E}=\mathrm{E}_{0} \cdot\left(1-\mathrm{a} \cdot \varepsilon_{1}\right)$

$\mu=\mu_{0}-\mathrm{b} /\left(\varepsilon_{1}-\varepsilon_{\infty}\right)$

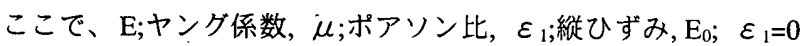
時のヤング係数，a, b, $\mathrm{E}_{0}, \mu_{0}$ および $\varepsilon_{\infty}$;実験定数

また、弾性係数は押出成形セラミックス材料の場合は異方性を考 慮して求める。

6. まとめ

実験結果および考察から以下の事項が結論できる。

1）ユニットに用いる材料の圧縮強度は、全形試験では求めること はできない。

2 ）圧縮強度および変形性状を明らかにするためには、実際のユニ ットから切り出した小形の試験体によることが有効である。

3 ） コンクリートおよびセラミックスユニットの圧縮強度は、ヤン グ係数に対して放物線および直線で表される。また、ポアソン 比は圧縮強度の上昇とともに一定值に安定する。

4 ）コンクリートユニットの圧縮時における臨界応力度およびひ ずみ度は、一般的な現場打設コンクリートより優れているが、 モルタルよりは劣っている。

5 ）セラミックスユニットの圧縮時における臨界応力度とひずみ 度との関係は、広範囲であり、終局圧縮強度に加えて臨界応力 度とひずみ度とを確認することが必要である。

6 ）押出成形によるセラミックスユニットは、圧縮強度・ヤング係 数およびポアソン比において異方性があり、その傾向は低強度 となるほど著しい。

7 ）ヤング係数およびポアソン比は縦ひずみに対して直線および 双曲線によって定量的に表現できる。

注

*1 メーソンリー構造という用語は最もグローヴァルであり、日本建築学会 建築工事標準仕様書においても採用されている。

*2 粘土焼成棟瓦の JIS は、JIS R 1250（普通棟瓦）と JIS A 5210 （建筑用セ ラミックスメーソンリーユニット) とでは、全く異なる試験法が採用さ れており、どちらを採用すべきか明確でないたけけでなく、当然結果も不 統一となる。

*3 煉瓦は、一部に粘土焼成したユニットの意味で用いられるが、国際的に は長さモデュールか $300 \mathrm{~mm}$ 以下のユニットの意味で使用されているの で、ここでは後者の定義によった。また、 $300 \mathrm{~mm}$ 以上はフロックと呼称 され、両方を総称してユニットという。

*4 Table 1 は一部最近改定されたものについては、制定年を明記して旧基準 を示している。

*5 セラミックスやコンクリートといった脆性材料が圧縮加力されるときは、 ひび割れの進展を伴う破壊となることを前提として、破壊開始状態や不
安定破壊への臨界状態は体積膨張にようて観察されると仮定して、変位 計やひずみゲージを破壞検知センサーとして用いる手法として位貴つけ できると考える9。

*6ここで、加圧盤が厚いという状態は付図に示す条件を满たすということ であり、このtより加圧盤厚さが小さいと現実の圧力分布が中央部にお いてより大きい状態となり、圧縮割裂状態となって試験体に縦割れを生 しることによってより小さい強度値となることが既往の研究で示されて いる ${ }^{10 \%}$

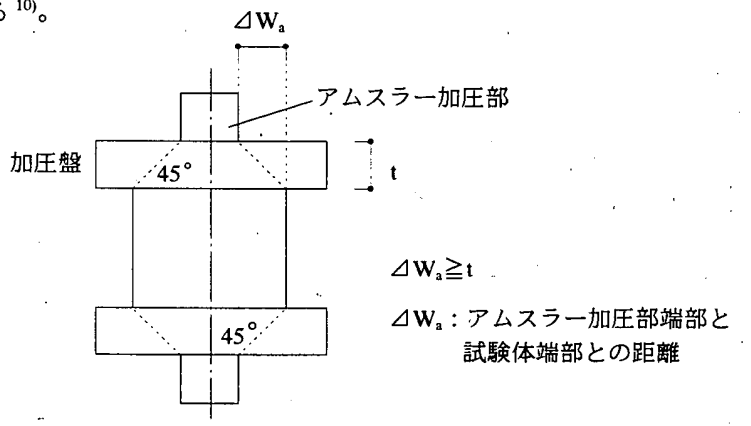

付図 加圧盤の厚さの最小值の求め方

*7 ここで、グラウトコンクリートとしては水セメント比 $57 \%$ 、スランブ 21 の川砂・川砂利を用いた（ともに鬼怒川岸）普通コンクリート、目地も ルタルとしては骨材最大寸法を $2.5 \mathrm{~mm}$ の川砂（鬼怒川岸）、細骨材セメ ント比 (S/C) 2.5 のフロー170 とし、グラウトモルタルは骨材最大寸法 を $5.0 \mathrm{~mm}$ の川砂（鬼怒川岸） $\mathrm{S} / \mathrm{C}$ を2.5、コンクリートスランプを 24 と した。

*8 Figure12 におけるセラミックスユニットは、穴あき断面形状であり、各 種強度および応力度は、穴を含めた評価となっているため、ここでは全 般的な材質の傾向と同一で取り扱うことができないと考えられる。

謝辞

この研究は、組積造の耐震性に関する日米共同研究および文化財建造物の 耐震調查において実施された研究を取りまとめたものであり、こ協力をいた たいた多くの人々に感謝いたします。また、本研究の一部は故渡辺光良氏、

松島泰幸氏の協力によるものであり、ここに謝意を表します。

\section{参考文献}

1) Akio Baba, Osamu Senbu, Mitsuyoshi Watanabe and Yasuyuki Matsushima, Mechanical Properties of Masonry Units and Test Methods for Determining Compressive Strength, BRI Research Paper No.118, Dec. 1985

2）日本工業規格 普通煉瓦 JiS R 1250-1981

3）日本工業規格＼cjkstart空洞コンクリートブロックＪIS A 5406-1979

4) 日本工業規格 セラミックフロック JIS A 5210-1975

5) "Sampling and Testing Clay Masonry Units" ASTM C 67-81

6) "Sampling and Testing Concrete Masonry Units" ASTM C 140-75

7) "Clay Bricks and Blocks" BS 3921:"74

8) "Mauerwerk" DIN 1045

9) S. P. Shah and S. Chandra, "Critical stress, volume change and micro cracking of concrete," ACI Journal Sept., 1968

10) M. W. Self, "The structural properties of load-bearing concrete masonry," EIES Project D-622, Engineering and Industrial Experimental Station, University of Florida, March 1974

11) 河原利江, 馬場明生, 守 明子, 長谷川直司, 高村功一: 文化財棟瓦造建 筑物の長期保存判定基準に関する研究 その 2 棟瓦および組積体の圧縮 性状，日本建築学会大会学術講演梗概集 (東海), A-1, pp.141-142, 2003.9 